\title{
$\mathrm{PH} 102$ actualitad
}

\section{Alumnado de la Universidad de Sevilla recopila en un blog legislación sobre el patrimonio cultural}

El blog es una iniciativa del alumnado de cuarto curso del Grado de Conservación y Restauración de Bienes Culturales de la Universidad de Sevilla. Con el bagaje de experiencias anteriores, la versión actual se pone en marcha el pasado curso 2019-2020, aspirando a convertirse en una herramienta no solo para estudiantes de la materia, sino para el conjunto de profesionales de la conservación y restauración de bienes culturales.

María Dolores Ruiz de Lacanal | Dpto. Escultura e Historia de las Artes Plásticas, Universidad de Sevilla

URL de la contribución <http://www.iaph.es/revistaph/index.php/revistaph/article/view/4814>

Cuando pensamos en Bellas Artes, se nos vienen a la cabeza muchas palabras; entre ellas, imaginación, libertad, belleza, creación, estética, pero no las palabras "conservación" o "legislación".

Sin embargo, la relación es bien estrecha y consolidada. Comienza con los orígenes de la vida humana, en el momento en que las sociedades o colectivos humanos comprenden que la supervivencia dependerá de las dinámicas de creación y de destrucción y que su regulación pasa por lo que llamamos civilidad ${ }^{1}$, civilización o humanidad.

Desde sus orígenes, la humanidad protege aquello que le resulta valioso. ¿Qué es valioso? Aquello que permite la supervivencia, siendo importante mantener la conciencia de quienes somos (identidad), la memoria de lo que fuimos (Historia o memoria)... Conservamos aquello que es y resulta de interés.

Podemos decir, como reflexión que aquello que no se estima se abandona, se olvida o se destruye. Conservación y creación son tareas humanas siempre complejas, basadas en la selección, que trabajan constantemente en la construcción y defensa de los valores de una sociedad.

Sin embargo, no es hasta muy recientemente, en el siglo $X X$, cuando la creación y la conservación vienen a confluir en el ámbito educativo. Y lo hace en el contexto de

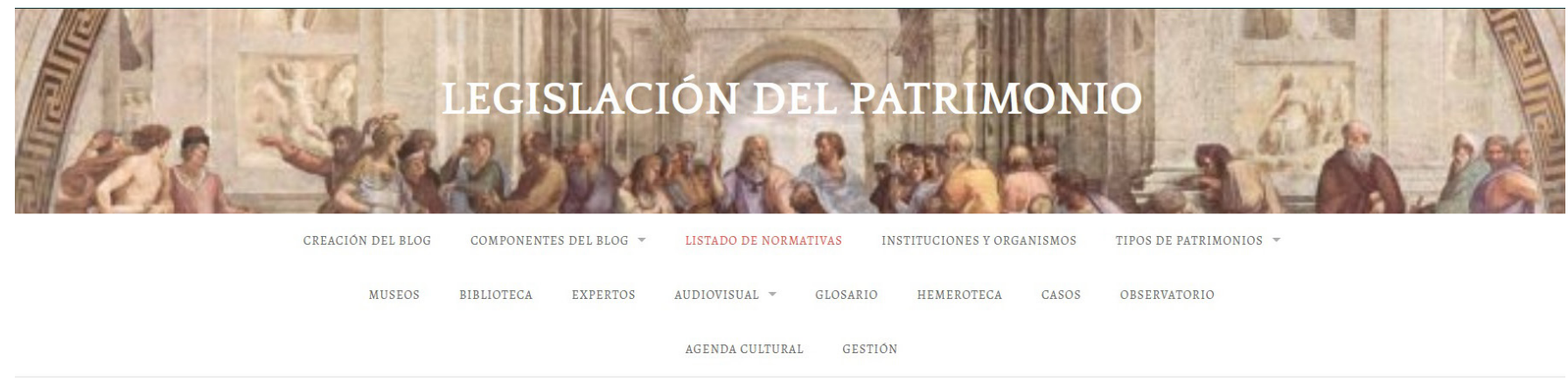

Listado de Normativas 
las enseñanzas artísticas, en las Facultades de Bellas Artes, donde recientemente surgen dos grados, uno para la enseñanza de Bellas Artes (creación) y otro para tutelar su conservación (Conservación y Restauración de Bienes Culturales).

Quizás sería un buen momento para explicar por qué urgen estas enseñanzas a finales del siglo XX y no antes, por qué se transformó la formación en restauración de obras de arte en la formación en conservación y restauración de bienes culturales. La respuesta es que este siglo y no antes despertó a Europa del sueño ilustrado, con la pesadilla de las guerras mundiales, mostrando que la restauración o la educación no sería suficiente ante la capacidad de destrucción y devastación del hombre moderno y "civilizado". El cuerpo de la legislación se ha ido desarrollando con conceptos, términos y medidas para la defensa del patrimonio.

Ahora presentamos el blog del alumnado², Legislación del patrimonio, de cuarto curso de Conservación y Restauración de Bienes Culturales que puede consultarse en https://legislacion2020.wordpress.com/archivo

El contenido queda organizado en función de diferentes tipos de patrimonio: patrimonio natural, etnográfico, científico-técnico, monumental y arquitectónico, documental y bibliográfico, entre otros.

Los documentos (recomendaciones europeas) se estructuran en orden cronológico y aún quedan por añadir las leyes nacionales y autonómicas, de manera que queda abierto a proyectos futuros.

Cada ámbito ha generado un vocabulario específico que configura un diccionario o glosario, un registro bibliográfico, un gran banco de imágenes, un conjunto de casos o un conjunto de videos. Todo ello se completa con una ingente cantidad de registros o informaciones relativas a organismos, expertos, bibliografía y prensa. Así, desde "Instituciones y asociaciones", lleva a diversas pestañas presentando aquellas que aparecen en los documentos (recomendaciones, convenciones y declaraciones); "Personajes" ha seleccionado personas relevantes del ámbito del patrimonio y de la cultura; y el "Glosario" com- prende palabras claves subrayadas y extraídas de los documentos que se presentan.

El blog está dirigido a nuestros alumnos, pero también a estudiantes de otras disciplinas que están relacionadas con la cultura, en general, o el patrimonio, como derecho, historia del arte, antropología, bellas artes, etc., pero también puede ser útil a los profesionales de la conservación y restauración de bienes culturales.

Aunque este blog se crea en el curso 2019-2020, no es el primero. Tres experiencias anteriores, con diferentes propuestas, han permitido conocer diferentes posibilidades e ir mejorándolo en cada edición. Y aún queda mucho por hacer. Ahora hay que dar un paso más, revalidar este trabajo por los investigadores y profesionales. Es por ello que la página web será revisada por el Grupo SOS Patrimonio (HUM 673) de la Universidad de Sevilla y por el Grupo SOS Patrimonio del IIC Grupo Español, por lo que esperamos un proceso de mejora y continuidad.

\section{NOTAS}

1. Comportamiento de la persona que cumple con sus deberes de ciudadano, respeta las leyes y contribuye así al funcionamiento correcto de la sociedad y al bienestar de los demás miembros de la comunidad.

2. Agradecemos el esfuerzo a las personas implicadas en el proyecto: María del Carmen Cea Fons, Paula Cruz Nieto, Pablo Gallego Roldán, José María Granero Delgado, Manuel Carlos Hernández Romero, Teresa Lobeiras Hidalgo, Lucía López Espacio, Nerea Lorenzo Fernández, Francisco Jesús Luna Ramos, Laura Martín Gallardo, Eva María Medina Castell, Andrea Merino Vázquez, Anush Mirzakhanyan Mirzakhanyan, Clara Pacheco Reyes, Luis Padrón Ruiz, Andrea María Peral López, Héctor Robledo Barriel, Álvaro Soto López, Luis Suárez Serrano y Miguel Torralba García. 